\title{
Trends of Graduate Theses with the Subject of Education and Training Conducted on Creativity
}

\author{
Mustafa Dolmaz ${ }^{1, *} \&$ Genç Osman İlhan ${ }^{2}$ \\ ${ }^{1}$ Police Department, Sivas, Turkey \\ ${ }^{2}$ Social Studies Education, Faculty of Education, Yildiz Technical University, İstanbul, Turkey \\ *Correspondence: Police Department, Sivas, Turkey. E-mail: mdolmaz58@gmail.com
}

Received: July 11, $2020 \quad$ Accepted: September 8, $2020 \quad$ Online Published: October 14, 2020

doi:10.5430/wje.v10n5p61 URL: https://doi.org/10.5430/wje.v10n5p61

\begin{abstract}
The aim of this research is to examine the trends of the studies that address the education-training dimension of creativity in Turkey. The research was conducted using a qualitative research pattern. The data was collected and analyzed through document analysis. In the analysis of the data, the thesis analysis form developed by the researchers was used. One hundred and forty-five graduate theses studied between 2005 and 2019 in the field of education, which were allowed access by their authors, constitute the study group of this research. 114 of these works consist of graduate theses and 31 of them consist of doctoral theses. The graduate theses in the Council of Higher Education database were examined under a total of 10 titles according to their distribution over the years-educational levels, university distributions, institute distributions, branch distributions, methods and sub-methods, data collection tools, sampling/study groups, sampling methods, education level of the study group and thesis titles. As a result of the research, it was observed that although studies addressing the educational-educational dimension of creativity have increased at a certain level over the years, they are not at the desired point and have not been studied adequately. In addition, it was determined that the studies carried out in terms of the discipline, the methods used and the variety of topics studied had similarities, that no studies on creativity were conducted in some departments, that the study group usually consists of a single level of education, that this situation does not allow to look at creativity from a broad perspective, and that there are many aspects of creativity that have not been studied for those who will work in the educational dimension.
\end{abstract}

Keywords: education, training, graduate studies, theses, creativity

\section{Introduction}

Creativity is a skill that has always been the focus of attention from the very first day of human existence to the information age we are in (Kiper, 2016). Creativity, one of the most fundamental characteristics of humanity, is not only an innate instinct and a way of thinking that every person has but also physical, biological, and psychological needs (Özerbaş, 2011; Onur\&Zorlu, 2017; Cannatella, 2004).

While it is known that information is rapidly changing and evolving, that information production and use are intensifying and technological developments are gaining momentum, this wind of development and change is another known fact that it brings more problems and problems with it (Kılıç \& Tezel, 2012; Hotaman, 2011). The ability of societies to capture this pace of change and to produce solutions to issues and problems experienced in energy, health, industrialization, urbanization and, perhaps most importantly, education is directly proportional to the potential for raising creative individuals (Öz-Aydın \& Ayverdi, 2014; Karakuş, 2001; Gök \& Erdoğan, 2011; Aktamış $\&$ Ergin, 2006). When we look at the nations that have developed in all fields and maintained their existence throughout history, it is possible to see traces of the value given to creative thinking and creativity skill (Ersükmen, 2010). It is no coincidence that societies with creative individuals lead others, and are further ahead in technological and economic terms (Iş̧1k, 2013). One of the most effective ways to improve the quality of life and to live in prosperity is to educate individuals as individuals who can think creatively and find creative solutions to problems (Öncü, 2018; Özerbaş, 2011).

The pre-school period is the most critical period to raise individuals as creative citizens because this is the period 
when the creativity potential of individuals begins and it almost peaks by the age of thirteen (Ömeroğlu, 1988). The child, by adding all his experiences on top of each other, begins to establish a network of relationships among them. Through various stimuli around him, the child's abilities of reasoning, creativity, and imagination develop (Kiper, 2016; Can Yaşar \& Aral, 2010). However, when children start school and become students, in other words, when they participate in the socialization process, their creativity will be dulled if they encounter an authoritarian and restrictive environment and a rote educational pattern (Gartenhaus, 1997). However, in order to be creative, children who are individuals of the future need to have self-confidence, think independently, go outside the usual patterns, encounter a free environment where they can use their own abilities to the full extent (Kurtzberg, 2005; Can Yaşar \& Aral, 2011). It is possible to find a great number of negative examples on this subject until the recent past. While the individual's natural creativity led him to seek answers to some of the problems he faced, the education system did not provide him with information on how to look for and evaluate these answers, nor did it allow him to use his abilities (Dolmaz \& Kaya, 2018; Gökalp, 2016). In line with the purposes of rote education, students were forced to memorize certain dates of the past, punctuation rules, and multiplication tables even in high school years, and were motivated to behavioral patterns. Thus, "to invent with imagination was sacrificed to do the practical and right" (Torrance, 1977; Gartenhaus, 1997). However, a new curriculum was prepared in line with the constructivist approach as a result of the effort to educate individuals in accordance with the requirements of the age and with the new education curriculum, creativity skills have been brought to the fore like other fundamental life skills. Thus, among the common skills that many disciplines aim to develop, creativity has found itself a place (Atasoy, Kadayıfçı \& Akkuş, 2017; Dolmaz, 2017; Tezci \& Gürol, 2003).

At this point, today, having only mere knowledge is not considered sufficient by societies. Diplomas held by individuals are seen as a basic requirement, and individuals are expected to have several high-level thinking and life skills in addition to their diplomas. Entrepreneurship, communication, critical thinking, innovation, information-using and communication technologies, problem solving, and creativity are among the most important skills (Yanpar Yelken, 2009; Kesicioğlu \& Deniz: 2014). However, there is a need to place a separate emphasis on creativity skill here. Creativity is a skill that is employed in all aspects of life, in all professions, and at every stage of all sensory and intellectual activities (Dikici, 2006; Aral, 1999; Ağluç, 2013; Yenilmez \& Yolcu, 2007). An individual who has creativity skill, required widely, will make acquiring and developing other skills quite easy. Because individuals who can think creatively are also people who can critically look at events and situations (Gök \& Erdoğan, 2011), who can produce new and creative solutions to problems in different ways, who are open to innovation and take risks (Yontar, 1993), who are curious and entrepreneurial, who ask-question and who are effectively successful in using science and technology (Kara \& Şençiçek, 2015; Karabey, 2010).

From health sciences to social sciences, from science to mathematics, all the inventions that will contribute to the future of humanity in all aspects of life will be realized by the use of human creative skills. Creative thinking, which will make life easier by adding new horizons to the lives of societies, can be developed through the education of individuals (Öztürk, 2001). In creative education, it is possible to look at events in a multifaceted way, to take advantage of much information, and to produce different and effective solutions (Kiper, 2016). Creativity is of particular importance for an effective educational environment that will enable future doctors, bankers, teachers, scientists, in other words, future generations to grow. The existence of creative individuals in fields such as business, art, technology, and science is directly related to the creative education system of societies. Creative individuals are also protected by society and institutions in which they reside (Ersükmen, 2010), because individuals, institutions and societies always try to be one step ahead of others. Today, being rational, self-renewing, making quick and flexible decisions in the time of sudden problems, and putting original products with existing information is highly valuable as events and problems are fluid, dynamic and spontaneous (Karakuş, 2001; Aktamıs \& Ergin, 2006; Ananiadou \& Claro, 2009). Access to all kinds of information is easier in today's world, so importance of the possession of information is replaced by the ability to use information. At this point, the important thing is to create value by putting something new on top of what exists (Demir, 2013).

When literature is examined, it was observed that the graduate thesis studies in almost every field were examined by the field experts (Oruç \& Ulusoy, 2008; Şahin, Göğebakan, Yıldız \& Duman, 2011; Akyol \& Yavuzkurt, 2016; Oğuz Haçat \& Demir, 2019; Küçükoğlu \& Ozan, 2013; Kurtdede-Fidan \& Öner, 2018; Bahar \& Kiras, 2017; Şimşek \&Yaşar, 2019; Dikmenli, Öztürk Demirbaş \&Yakar, 2018; Gür Erdoğan, Kaya Uyanık \& Canan Güngören, 2018; Sönmez, 2017; Karadağ, 2014; Akkaşoğlu, Akyol, Ulama \& Zengin, 2019; Şenyurt \& Özer Özkan, 2017; Oruç \& Erdoğan, 2018). Examination of scientific research on a subject can both provide information about the qualities of research on that subject and contribute to the study of the literature on that subject. In addition, the examination of published studies may shed light on new studies that will be carried out later (Kurtoğlu \& Seferoğlu, 2013). 
When graduate studies on creativity, which are considered to have an important impact on the future of societies and which are considered to be among the most important skills of the future (Craft, 2001), are examined, it was found that they are few in number. As creativity is a skill that concerns almost every field provides researchers with great opportunities in terms of subject and depth. This study is implemented with theses on education-training conducted in the field of creativity is expected to contribute to the field since it would determine trends of the field by analyzing the distribution of the studies made in the last 15 years and would guide the new studies.

\section{Aim of the Study}

The main purpose of this research is to determine the trends of graduate thesis studies conducted on creativity with the subject of education-training. In line with this main purpose, answers will be sought for the following sub-purposes:

- How do theses on creativity differ according to the years and levels of education?

- How do theses on creativity differ according to the universities they are conducted in?

- How are theses on creativity distributed according to the institutes in which they are conducted?

- How do theses on creativity differ according to the departments in which they are conducted?

- How do theses on creativity differ according to research methods and sub-methods?

- How do theses on creativity differ according to the number of data collection tools used in research?

- How do theses on creativity show a distribution according to study groups/sampling?

- How do theses on creativity differ according to sampling methods?

- How do theses on creativity differ according to the level of study group/sampling?

- How are theses on creativity distributed according to the subject areas related to their titles?

\section{Method}

\subsection{The Research Model}

The research was conducted by adopting a qualitative research pattern. Qualitative research enables the subject to be described and interpreted in-depth with a holistic approach (İslamoğlu \& Alnıçık, 2014). In this study, the document review method, which is one of the qualitative research methods, was used. Document review involves a systematic examination of written, printed and electronic sources that contain information about the data within the scope of the research (Yıldırım \& Şimşek, 2006; Maxwell, 2007; Bowen, 2009; Karadağ, 2014). Furthermore, in this method, it is essential to collect, review, query, and analyze documents that constitute the primary source of research data (O'leary, 2004 Cited in Özkan, 2019).

\subsection{The Study Group}

The study group of the research consists of theses with the subject of education and training, which were conducted on creativity between 2005 and 2019 and the titles of which were filtered with the terms 'creative' and 'creativity' and which were granted access. 145 graduate publications analyzed in the meantime have formed the study group of the research. The reason why the starting point was chosen as 2005 is that creative thinking began to take part in curriculum put into practice in 2005. In the selection of the study group, criterion sampling, which is a variant of objective sampling, was used. Criterion sampling means selecting participants according to definite criteria such as particular characteristics, events, objects or situations (Büyüköztürk, Çakmak, Akgün, Karadeniz \& Demirel, 2011). The sampling criteria for this research was determined that theses should be prepared between 2005 and 2019 , include the terms 'creative' and 'creativity' in their title, and be conducted in the field of education-training and be accessible.

\subsection{Data Collection and Analysis}

In order to collect the data, the graduate theses that are filtered according to certain criteria in the YÖK National Thesis Center Database were transferred to the computer in pdf (portable document file) format. The analysis form was prepared by the authors in line with the research questions. In the preparation of the thesis analysis form, the views of two field experts, excluding researchers, were applied for language and field validity and reliability. In accordance with the views and suggestions, a pilot application was made with 20 graduate theses and the form was given its final form. The form, in its final form, has created an opportunity to collect information about the years they 
were studied, what level of education they were prepared, universities-institutes-departments they were studied, study groups/ samplings, sampling methods, sampling group selection education levels, research methods, data collection tools used in research theses within the scope of the research and allowed thesis titles studied to be classified into categories. For the reliability of the form, the compatibility between coders was controlled by the formula (reliability=Consensus/(Consensus + Dissensus) proposed by Miles and Huberman (1994), and the compatibility rate between coders was found to be $100 \%$.

\subsection{Limitation of Research}

The research is limited to the Turkish graduate thesis studies which were studied at the state and foundation universities in Turkey between 2005 and 2019 and which are open to access in the database of YÖK (Higher Education Council) publication and documentation department, contain the words 'creative' and 'creativity' in the title content and have the expression of education and training in the subject section on thesis scanning screen.

\section{Findings}

In this part, several findings on the graduate theses with the subject of education and training conducted on creativity between 2005 and 2019 can be found.

\subsection{Findings on Distribution of Graduate Theses with the Subject of Education and Training Conducted on Creativity According to Years and Education Levels}

The distribution of graduate theses on creativity according to years and education levels is given in Chart 1 . As shown in Chart 1, a total of one hundred and forty-five graduate thesis studies which were studied between 2005 and 2019 and were accessible in the YÖK database were found and it was determined that one hundred and fourteen of these studies were studied at the graduate level and thirty-one at the doctoral level.

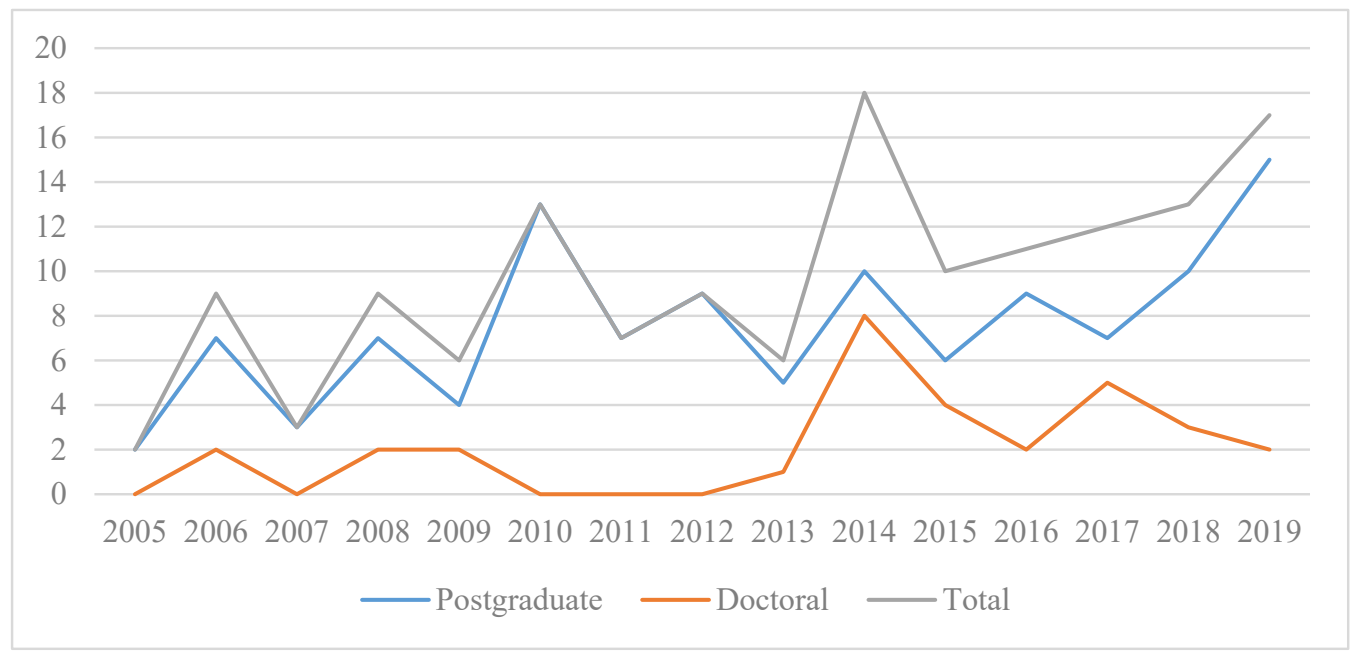

Figure 1. Distribution of Graduate Theses on Creativity According to Years and Education Levels

When Figure 1 is examined, it is seen that two graduate theses were made in 2005, seven graduate and two doctoral theses in 2006, three graduate theses in 2007, seven graduate and two doctoral theses in 2008, four graduate and two doctoral theses in 2009, thirteen graduate theses in 2010, seven graduate theses in 2011, nine graduate theses in 2012, five graduate and one doctoral thesis in 2013, ten graduate and eight doctoral theses in 2014, six graduate and four doctoral theses in 2015, nine graduate and two doctoral theses in 2016, seven graduate and five doctoral theses in 2017 , ten graduate and three doctoral theses in 2018, and fifteen graduate and two doctoral theses in 2019 . The year in which the most theses conducted on creativity is 2014. The year in which the least number of theses conducted is 2005. The number of theses conducted on creativity after 2014 has fallen behind that of 2014 . As of 2015, a limited number of studies were conducted, however, they have begun to show a steady increase. In the context of the number of theses accessible as of September 2019, the studies in 2019 are only one less than the number of theses studied in 2014. In 2005, 2007, 2010, 2011 and 2012, no doctoral theses have been published on the subject studied, two doctoral theses have been conducted in 2006, 2008, 2009, 2016 and 2019, and four in 2015 and five in 2017. In 2014, eight doctoral theses were conducted, and the year in which the most doctoral theses were studied was 2014 . The 
year in which the most graduate theses was studied is 2019.

4.2 Findings of Graduate Thesis Studies with the Subject of Education-Training Conducted on Creativity According to Universities in Which They Are Studied

Figure 2 displays the names of universities and the number of graduate studies conducted on creativity between 2005 and 2009. In Chart 2, which examines the universities where thesis studies conducted on creativity between 2005 and 2019 , the top 30 universities (in terms of number of creativity these) where creativity graduate theses were conducted are given.

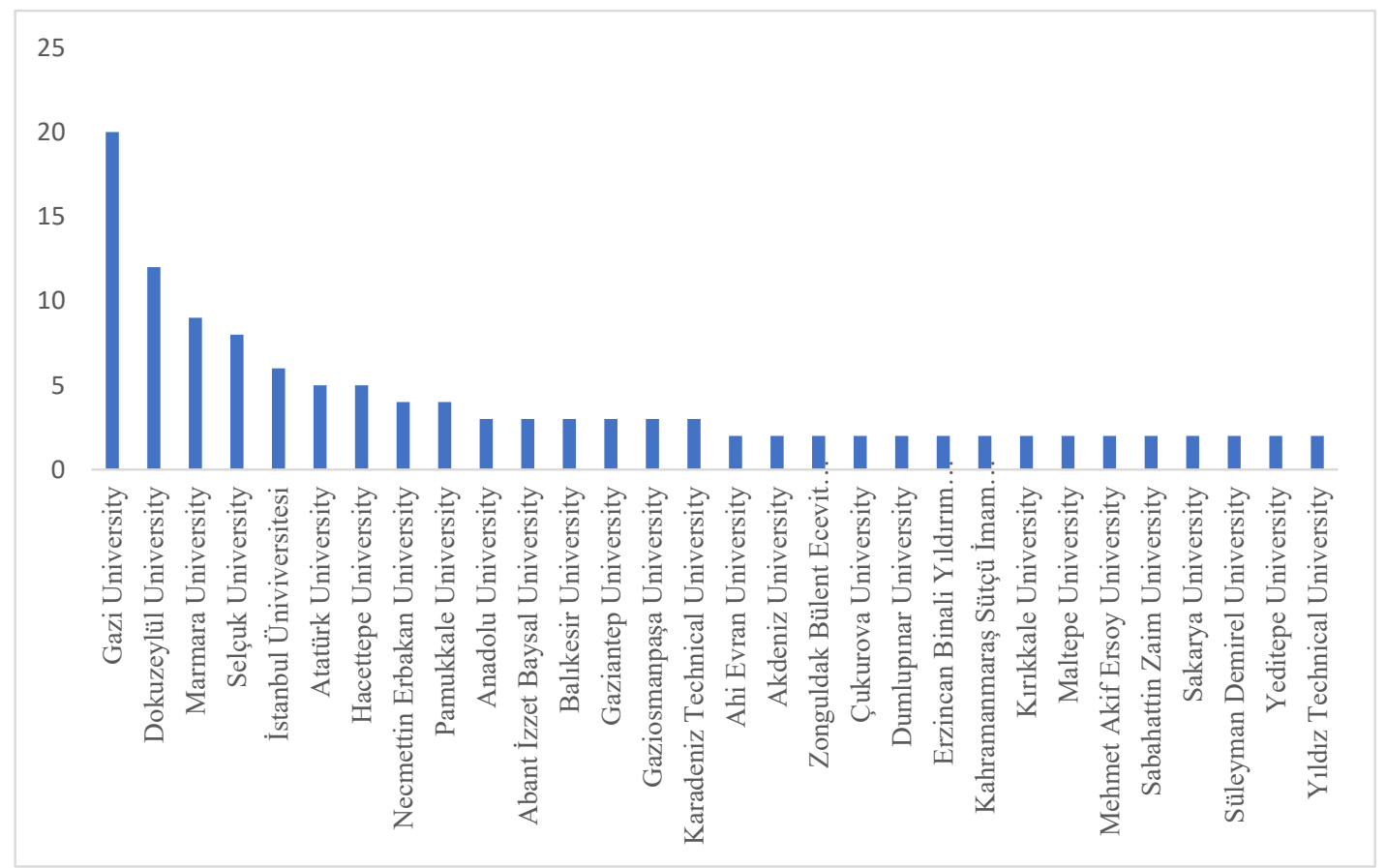

Figure 2. Distribution Numbers of Graduate Theses with the Subject of Education-Training Conducted on Creativity according to Universities

In total, 145 graduate thesis studies on creativity were conducted at 52 universities. According to Chart 2, most thesis studies were conducted by Gazi University (20). Gazi University is followed by, respectively, Dokuz Eylül University (12), Marmara University (9), Selçuk University (8), Istanbul University (6), Atatürk University (5), Hacettepe University (5), Necmettin Erbakan University (4), Pamukkale University (4), Anadolu University, (3), Abant İzzet Baysal University (3), Balıkesir University, (3), Gaziantep University, (3), Gaziosmanpaşa University, (3) and Karadeniz Technical University (3).Two thesis studies were conducted each in the other universities included in the chart. These universities are Ahi Evran University, Akdeniz University, Zonguldak Bülent Ecevit University, Çukurova University, Dumlupınar University, Erzincan Binali Yıldırım University, Kahramanmaraş Sütçü İmam University, Kırıkkale University, Maltepe University, Mehmet Akif Ersoy University, Sabahattin Zaim University, Sakarya University, Süleyman Demirel University, Yeditepe University, and Yıldız Technical University.

In the other 22 universities that were not included in the chart, it was seen that only one study was conducted in each university. These universities are Erciyes University, Adnan Menderes University, Ondokuz Mayıs University, İnönü University, Adnan Menderes University, Ankara University, Nişantaşı University, Dicle University, Üsküdar University, Çağ University, Adıyaman University, Bayburt University, Bartın University, Sivas Cumhuriyet University, Recep Tayyip Erdoğan University, Bahçeşehir University, Harran University, Muğla Sitkı Koçman University, Ege University, Niğde Ömer Halisdemir University, Eskişehir Osmangazi University, Celal Bayar University. When the distribution of the number of graduate theses with the subject of education-training conducted on creativity is examined, it is seen that 1-2 studies have been conducted at almost all universities except for a few universities. 


\subsection{Findings on Institutes Where Graduate Thesis Studies on Creativity Conducted Between 2005 and 2019}

Information about the institutes where the graduate studies on creativity conducted between 2005 and 2019 are given in Figure 3.

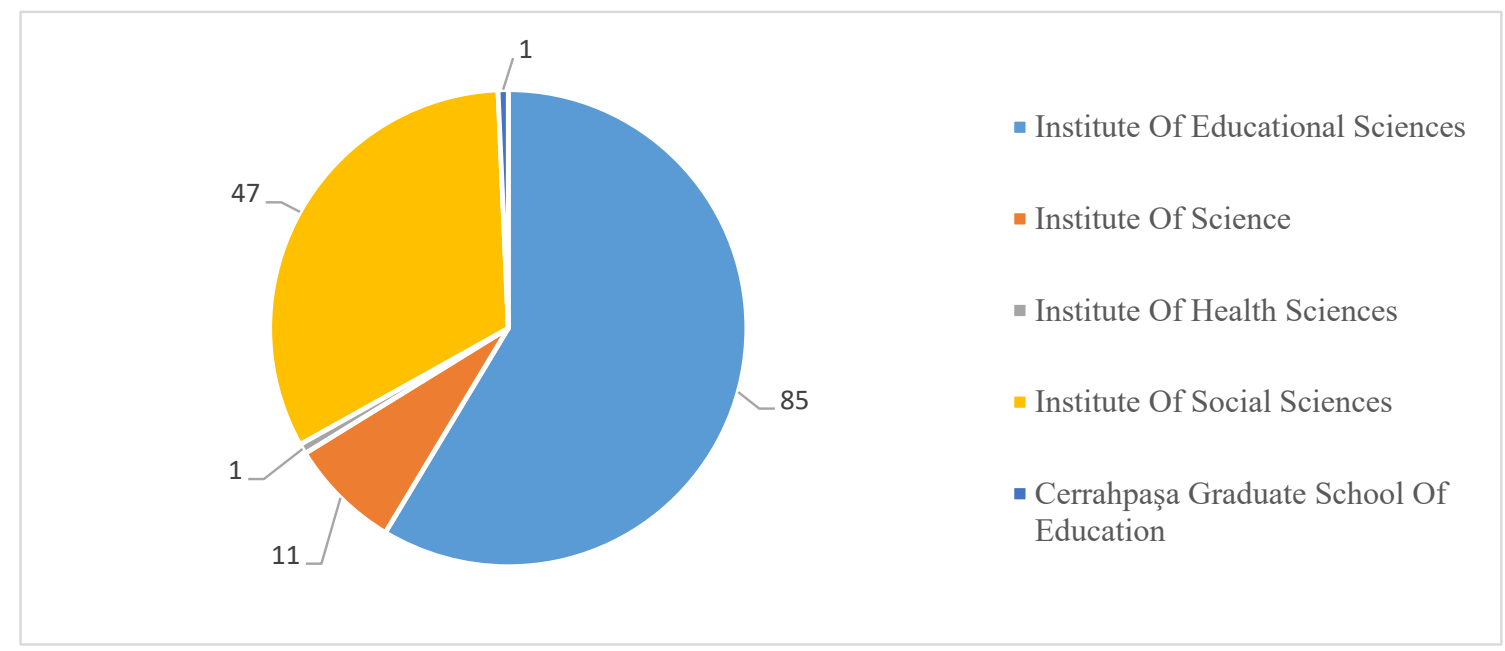

Figure 1. Data on The Institutes Where Graduate Theses with the Subject of Education-Training on Creativity Were Conducted

When Figure 3 is examined, it is seen that of one hundred forty-five thesis studies, eighty-five theses on creativity were studied at the institute of educational sciences, forty-seven at the institute of social sciences, eleven at the institute of sciences, one at the institute of health sciences and one at the Cerrahpaşa Graduate School of Education. In addition to the fact that the institute of educational sciences has the highest number of theses, according to other data obtained, almost all of the theses in the social sciences and science institutes have been delivered by the disciplines that train teachers.

4.4 Findings on Graduate Thesis Studies with the Subject of Education-training on Creativity, according to the Disciplines in Which They Are Conducted

Data regarding the number and disciplines of graduate studies conducted in various departments of universities are given in Chart 4. As given in Chart 4, Science Education is the area where theses on education and training in the field of creativity are most studied.

In the field of Science education, twenty-one graduate studies were conducted. Science education is followed by "Class Education" with sixteen graduate theses, "Education Management, Inspection, Planning and Economics"“Education Programs and Teaching", "Preschool Education", "Mathematics Education"disciplineswith eleven studies. Ten theses have been prepared each in "Child Development and education" and "Art Teaching". Respectively, eight studies were conducted in the "Educational Sciences", six in the "Intellectual Giftedness Education", four in the "Guidance and Psychological Counseling", and three in the "Turkish Education". Two studies were conducted each in "Fine Arts Education", "Psychology Education", "Social Studies Education", "Educational Technology", "Chemistry Education", "Physical Training and Sports Education" and "Music Education" fields.

Furthermore, apart from these disciplines, thesis studies on creativity were conducted in nine more disciplines. However, the first nineteen disciplines are included in the chart. The rest of nine disciplines have only one gradute thesis on creativity. These branches are the departments of "Clinical Psychology", "Education of Mentally Handicapped", "Life-long Learning", "Vocational Drawing Education", "Computer and Teaching Technologies", "Program Development in Education", "Turkic Studies", "Special Education" and "Biology Education".

Although a total of twenty-eight scientific studies have been conducted on creativity in education and training, the number of studies carried out remains relatively low. Only one or two studies have been conducted in most of the disciplines in education; however, in many sciences such as history, geography, and physics education, no studies on creativity have been found. 


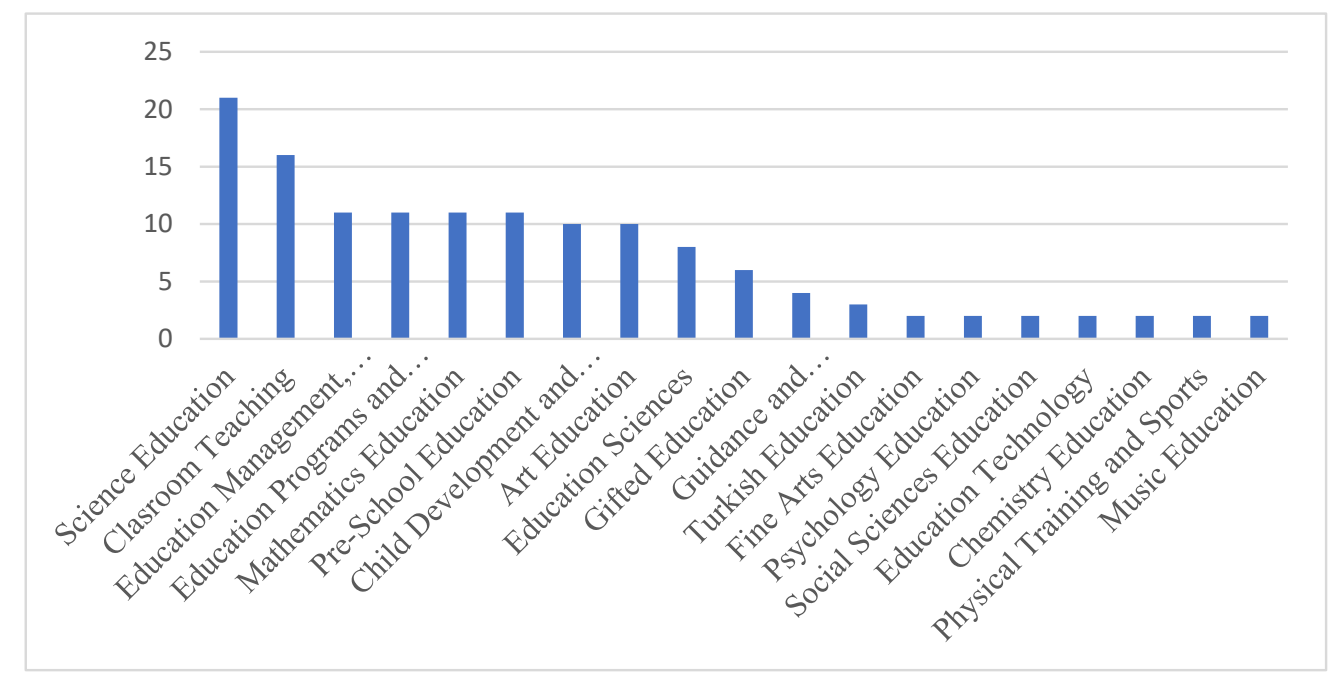

Figure 2. Disciplines of Graduate Studies with the Subject of Education-Training on Creativity

4.5 Findings of Graduate Thesis Studies Conducted during 2005-2019 with the Subject of Education-training on Creativity, According to Their Methods

The methods of graduate studies conducted during 2005-2019 with the subject of education-training on creativity are given in Figure 5 and Table 1.

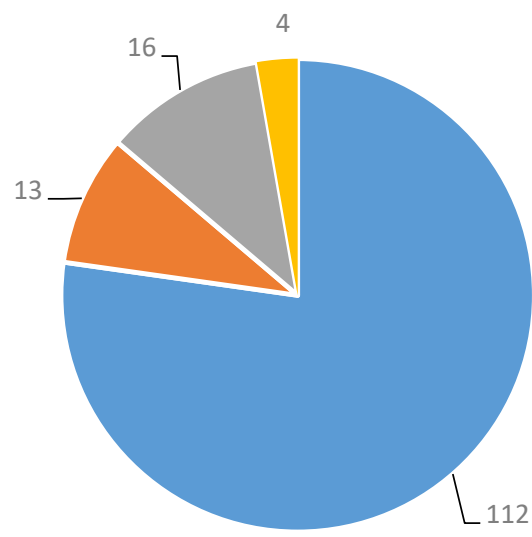

- Quantitative

- Qualitative

- Mixed

- Unidentified

Figure 3. Research Methods Used in Graduate Thesis Studies Conducted during 2005-2019 with the Subject of Education-training on Creativity

Among the theses on creativity, 112 were conducted with quantitative method, 16 with mixed method, and 13 with qualitative method. The majority of the 112 quantitative studies $(n=59)$ were studied with survey method. The number of researches studied in the experimental pattern is thirty-four and the number of semi-experimental studies is seventeen. One of the remaining two studies is a causal comparison and the other one is correlational research.

Five of the graduate theses studied in the qualitative pattern are case studies and three are document review studies. Only one study was conducted for each of the complementary assessment, observation, and literature review methods. In one research, document examination and interview methods were used together and in one research, document examination, interview, and observation methods were used together. In research with qualitative patterns, the most preferred method is observed to be the case study.

Of the sixteen studies patterned by the mixed method, five were studied with nested patterns, four with the explanatory sequential pattern, and two with convergent parallel patterns. In five studies, the methodology (it was mixed method) was not specified by the author of thesis and they were therefore placed under the category of 
unidentified.

Table 1. Research Methods Used in Graduate Studies with the Subject of Education-training on Creativity

\begin{tabular}{lcc}
\hline Research Methods & Frequency & Percentage \\
\hline Quantitative Methods & 59 & 40,6896 \\
Scanning Pattern & 34 & 23,4482 \\
Experimental Pattern & 17 & 11,7241 \\
Quasi-experimental Pattern & 1 & 0,6896 \\
Causal Comparison & 1 & 0,6896 \\
Correlational Search & 112 & 77,2413 \\
Subtotal & & \\
Qualitative Methods & 5 & 3,4482 \\
Case Study & 3 & 2,0689 \\
Document Review & 1 & 0,6896 \\
Integrative Evaluation & 1 & 0,6896 \\
Observation & 1 & 0,6896 \\
Document Review+Interview & 1 & 0,6896 \\
Document Review+Interview+Observation & 1 & 0,6896 \\
Literature Review & 13 & 8,9655 \\
Subotal & & \\
Mixed Methods & 5 & 3,4482 \\
Nested Embedded Pattern & 4 & 2,7586 \\
Explanatory Sequential Pattern & 2 & 1,3793 \\
Convergent Parallel Pattern & 5 & 3,4482 \\
Unidentified & 16 & 11,0344 \\
Subtotal & & \\
Unidentified & 4 & 2,7586 \\
Cannot be identified & 145 & 100 \\
Grand Total & & \\
\hline
\end{tabular}

In light of these findings, it is observed that the authors of graduate theses generally prefer quantitative research methods, followed by mixed-method patterned research and that the least preferred method is qualitative research methods.

4.6 Findings on Data Collection Tools Used in Graduate Thesis Studies with the Subject of Education-Training on Creativity

The data collection tools and usage numbers used in graduate studies with the subject of education-training on creativity are given in Table 2 .

Forty-four of 145 graduate thesis studies were studied with a single type of data collection tool. In twenty-five of the studies carried out with a single data collection tool used scales, in eight of studies used tests, in eight of studies used forms, in two of studies used questionnaires and in one of studies used clinical interview.

Of the sixty-six studies conducted with two types of data collection tools, twenty-one "test+form" was preferred in twenty-one, "scale+form" was preferred in eighteen, and "test+scale" was preferred in eighteen studies. In other studies with two types of data collection tools, "test+questionnaire", "form+rating scale", "form+inventory", "form+material", "observation notes+form", "scale+inventory", "event product+drawing", "form+survey" and "scale+ list" are each used once.

In twelve of the twenty-five surveys conducted with three types of data collection tools, "test+scale+form" was preferred. Then, respectively, "scale+form+inventory" was used three times, "scale+test+material" twice, "observation notes+form+test" twice, "scale+test+questionaire", "form+scale+list", "rubrics+log+scale", "test+inventory+form", "event product+observation notes+benchmark list", "form+observation notes+log", "questionnaire+form+scale" and "test+form+observation" notes were used once.

Of the six studies conducted with four types of data collection tools "test + inventory+scale + form" was used twice and the combinations of "test+form+drawing+rubric", "video recording+form+observation notes+activity product", 
"drawing+album+form+questionnaire" and "form+test+activity product+study sheet" were preferred once. In two studies, the use of the data collection tool was not specified, therefore, it could not be determined.

Table 2. Information on Data Collection Tools Used in Graduate Thesis Studies with the Subject of Education-Training on Creativity

\begin{tabular}{|c|c|c|}
\hline \multicolumn{3}{|c|}{ Frequency / Percentage Information of Data Collection Tools } \\
\hline \multicolumn{3}{|c|}{ Tools Used in Research with A Single Type of Data Collection Tool } \\
\hline & Frequency & Percentage \\
\hline Scale & 25 & 17,2413 \\
\hline Test & 8 & 5,5172 \\
\hline Form (Information/Interview/Observation Form) & 8 & 5,5172 \\
\hline Questionnaire & 2 & 1,3793 \\
\hline Clinical Interview & 1 & 0,6896 \\
\hline Subtotal & 44 & 30,3448 \\
\hline \multicolumn{3}{|c|}{ Tools Used in Research with Two Types of Data Collection Tool } \\
\hline Test+Form & 21 & 14,4827 \\
\hline Scale+Form & 18 & 12,4137 \\
\hline Test+Scale & 18 & 12,4137 \\
\hline Test+Questionnaire & 1 & 0,6896 \\
\hline Form+Rating Scale & 1 & 0,6896 \\
\hline Form+Inventory & 1 & 0,6896 \\
\hline Form + Material & 1 & 0,6896 \\
\hline Observation Notes+Form & 1 & 0,6896 \\
\hline Scale+Inventory & 1 & 0,6896 \\
\hline Event Product+Drawing & 1 & 0,6896 \\
\hline Form + Questionnaire & 1 & 0,6896 \\
\hline Scale+List (Exam Result List) & 1 & 0,6896 \\
\hline Subtotal & 66 & 45,5172 \\
\hline \multicolumn{3}{|c|}{ Tools Used in Research with Three Types of Data Collection Tool } \\
\hline Test + Scale + Form & 12 & 8,2758 \\
\hline Scale+Form+Inventory & 3 & 2,0689 \\
\hline Scale+Test+Material & 2 & 1,3793 \\
\hline Observation Notes + Form and Test & 2 & 1,3793 \\
\hline Scale+Test+Questionnaire & 1 & 0,6896 \\
\hline Form + Scale + List & 1 & 0,6896 \\
\hline Rubric + Log + Scale & 1 & 0,6896 \\
\hline Test+Inventory+Form & 1 & 0,6896 \\
\hline Activity Product + Observation Notes + Criteria List & 1 & 0,6896 \\
\hline Form + Observation Notes + Journal & 1 & 0,6896 \\
\hline Survey+Form+Scale & 1 & 0,6896 \\
\hline Test + Form + Observation Notes & 1 & 0,6896 \\
\hline Subtotal $\quad \ldots$ & 27 & 18,6206 \\
\hline \multicolumn{3}{|c|}{ Tools Used in Research with Four Types of Data Collection Tool } \\
\hline Test+Inventory+Scale+Form & 2 & 1,3793 \\
\hline Test+Form+Drawing+Rubric & 1 & 0,6896 \\
\hline Video Records + Form + Observation Notes + Activity Product & 1 & 0,6896 \\
\hline Drawing + Album + Form + Survey & 1 & 0,6896 \\
\hline Form + Test + Activity Product + Work Sheet & 1 & 0,6896 \\
\hline Subtotal & 6 & 4,1379 \\
\hline Non-admitted & 2 & 1,3793 \\
\hline Total & 145 & 100 \\
\hline
\end{tabular}


4.7 Findings Related to Study Groups / Sampling of Graduate Thesis Studies with the Subject of Education-Training on Creativity

Groups and group formation frequencies that are subject to study groups/sampling of graduate studies with the subject of education-training on creativity are given in Figure 6.

When the study groups of researches conducted between 2005 and 2019 are analyzed, it is observed that one hundred and eleven studies were conducted only with students and eighteen studies were conducted with teachers. While it can be determined that four graduate research was conducted with school administrators, one research with authors, one research with trainees, one research with pre-school children groups and one research with documents (books, articles, etc.), in one research, study group/sampling was not indicated by the author; however, as a result of the examination, it was determined that thesis was prepared as a literature review study. It was seen that four thesis studies were conducted with teachers and administrators; three thesis studies were conducted with students and teachers.

The most important point to note here is that the study group/sampling consists of only one group except for seven studies. In fact, one hundred and eleven studies were conducted with only students and eighteen studies were conducted with only teachers.

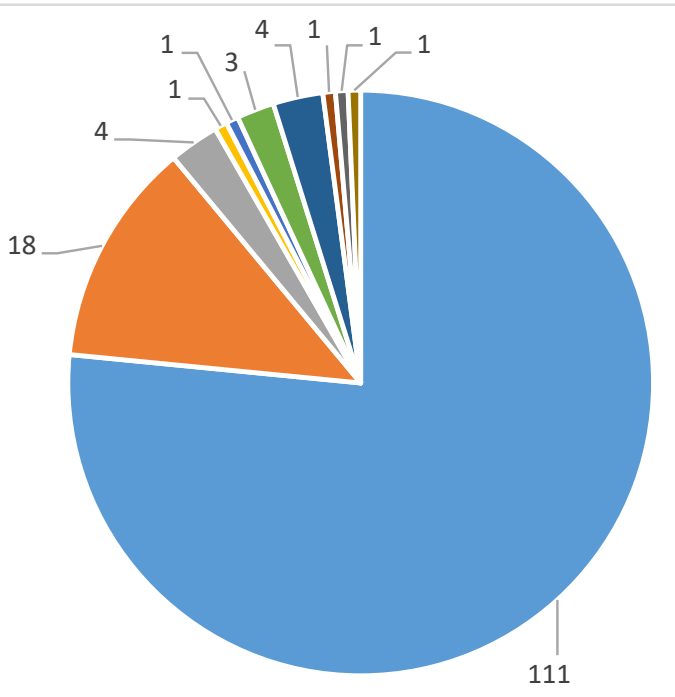

$$
\begin{aligned}
& \text { - Student } \\
& \text { - Teacher } \\
& \text { - Administrator } \\
& \text { - Author } \\
& \text { - Nonadmitted } \\
& \text { - Student+Teacher } \\
& \text { - Teacher+Administrator } \\
& \text { - Pre-School Group } \\
& \text { - Trainee } \\
& \text { - Document (Book, etc.) }
\end{aligned}
$$

Figure 4. Study/Sampling Groups and Frequencies of Graduate Studies with the Subject of Education-Training on Creativity

\subsection{Findings on Sampling Methods of Graduate Thesis Studies with the Subject of Education-Training on Creativity} Sampling methods of graduate thesis studies conducted during 2005-2019 with the subject of education-training on creativity are given in Figure 7. 


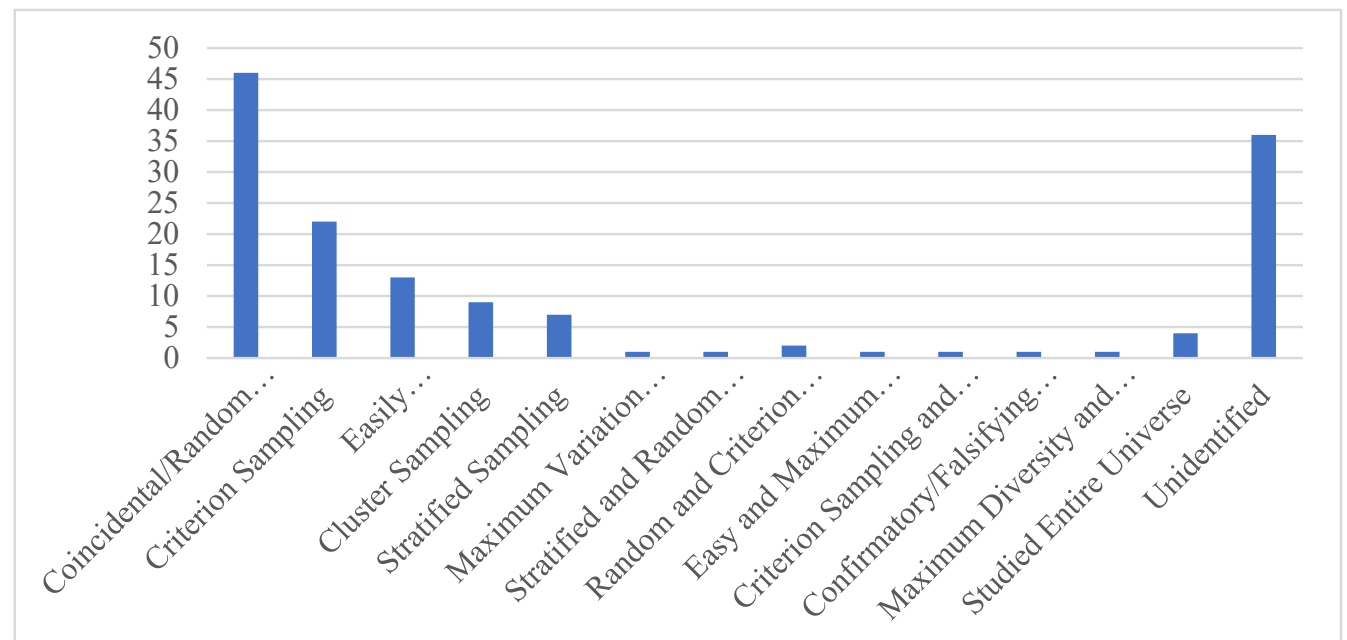

Figure 5. Sampling Methods Used in Graduate Thesis Studies Conducted during 2005-2019 with the Subject of Education-Training on Creativity

When the chart is examined, it could be understood that the most preferred sampling method was random sampling with forty-six frequency values. Following this sampling format, it was seen that the most preferred format was criterion sampling. Twenty-two graduate studies were conducted using criterion sampling. Thirteen researchers preferred the easily accessible/appropriate sampling format in their research. These sampling formats were followed by cluster sampling with nine studies, stratified sampling with seven studies, and maximum diversity sampling formats with one study Random and criterion sampling methods were used together in the two studies. Again, stratified sampling and random sampling methods, easy and maximum sampling methods and criterion sampling, and maximum variety sampling methods were used together once. In four studies, no sampling methods were used and the entire population was studied.

One of the most important points of note is the determination that there is no mention of the sampling method in thirty-six studies. In these studies, no sampling method was given by the authors so it could not be determined. It has been determined that only two of these studies may not contain samplings due to the nature of their methods (literature writing, document examination, etc.). In the remaining thirty-four studies, although they contain study/sampling groups, sampling methods were not given. This number represents a fairly high proportion of one hundred and forty-five graduate thesis work.

4.9 Findings on the Levels of Education in Which the Study Group/sampling is Selected in Graduate Thesis Studies with the Subject of Education-training on Creativity

Data on the education levels of the groups that make up the study group/sampling of graduate theses conducted on creativity between 2005 and 2019 are given in Figure 8. 


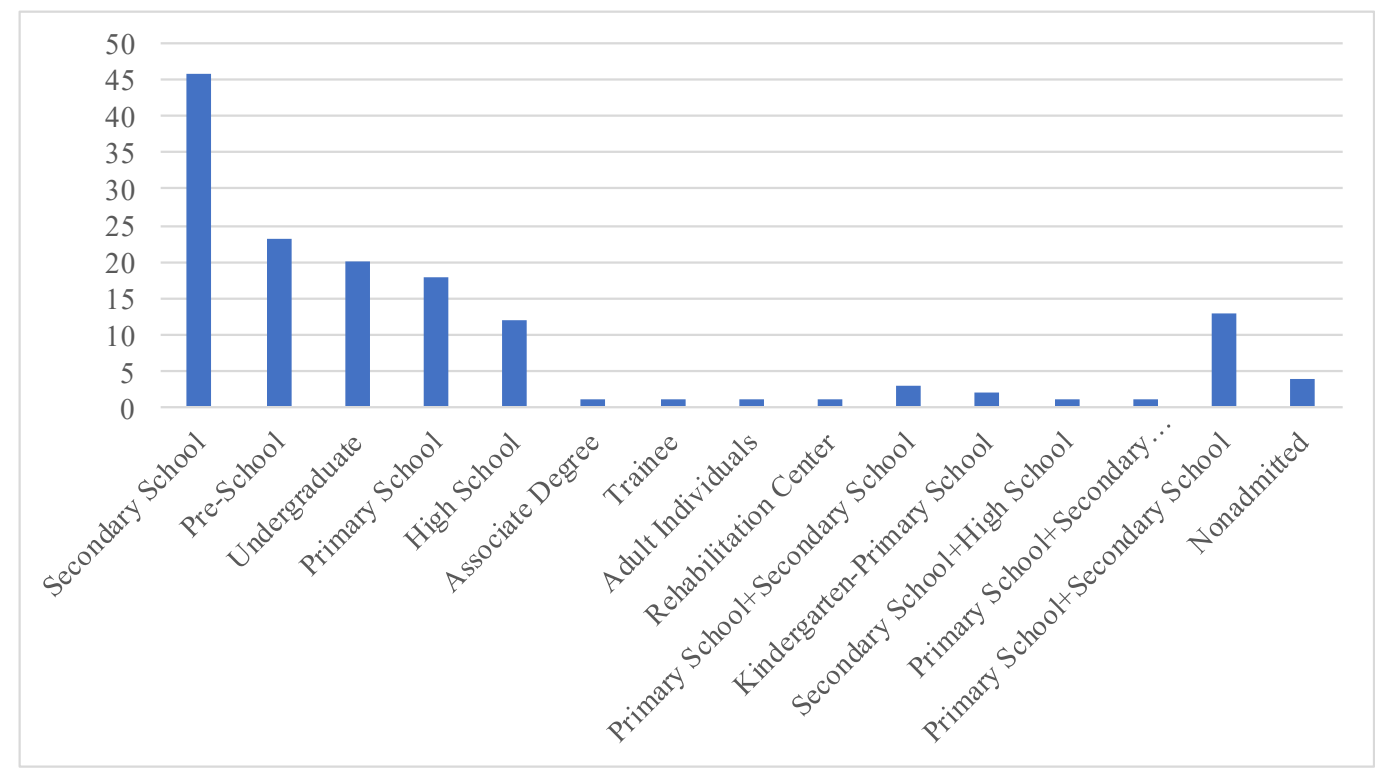

Figure 6. Education Level / Environment in Which the Sampling Group of Graduate Thesis Studies with the Subject of Education-training on Creativity is Selected

When Chart 8 is examined, the following can be said about the educational level in which the sampling/study group of one hundred and forty-five graduate studies is selected:

It was seen that forty-six studies showed that the sampling/study group was chosen from the secondary school level, twenty-three studies from pre-school (kindergarten) levels, twenty research from undergraduate (university) levels, eighteen studies from the primary school level, twelve studies from the high school level, two research from associate degrees, in one study from the trainees of a training center, although their education status is unclear, in one study from rehabilitation centers, although their education status is unclear and in one study from adults, although their education status is unclear as well.

Although not many, some studies have been conducted with different groups in the two levels of education. In thirteen studies, the sampling/study group was selected from primary and secondary school levels, in two studies from kindergarten and primary school levels, and in one study from secondary and high school levels. There is one study in which a study group/sampling is selected from the primary school, middle school, and high school levels. In four researches, no findings were found in this regard.

When the data in Chart 8 is evaluated generally, it is observed that the sampling group/study group is usually selected from a single level of education. It is observed that twenty researches are carried out with different levels of education and to provide data diversity.

\subsection{Findings on the Subjects Related to Graduate Thesis Studies with the Subject of Education-Training on Creativity}

Information on which subjects are studied for graduate thesis studies with the subject of education-training on creativity is given in Table 3 .

When Table 3 is examined, it is seen that most studies on creativity are conducted in twenty-three research and two titles. While the first of these was on the "relations of creativity with various teaching methods, strategies, techniques, and applications", the second one was on the relationship of "various variables and creativity" each with twenty-three studies. This title is followed with titles of "level of creativity" with twenty-two studies, "creativity in different fields" with twenty studies, "creativity in the context of writing, reading, speaking and thinking skills" with nine studies, "creative drama" with eight studies, "gifted individuals and creativity" with seven studies, "curriculum programs and creativity" with six studies, "creativity in the context of teaching approaches" and "creativity in the context of student and teacher views" with five studies each, "creativity in the context of arts and literature products" with four studies, "teaching materials and creativity" with three studies, "creative individual characteristics" and "individuals with special needs and creativity", "perceptions towards the concept of creativity" and "relationship 
between instructional technologies and creativity", with two studies each, "creativity components" and "creativity education" with one study.

Table 3. Data on the Subjects Related to the Titles of Graduate Thesis Studies with the Subject of Education-Training on Creativity

\begin{tabular}{lcc}
\hline \multicolumn{1}{c}{ Studied Related Field of Subject } & Frequency & Percentage \\
\hline Teaching Methods, Strategies, Techniques and Practices-Creativity Relationship & 23 & 15,8620 \\
Various variables and Relationship of Creativity (Age, Gender, Academic Achievement, etc.) & 23 & 15,8620 \\
Creativity Level (Teacher, Student, Teacher Candidate, etc.) & 22 & 15,1724 \\
Creativity in Different Fields (Scientific, Organizational, etc.) & 20 & 13,7931 \\
Creativity in the Context of Writing, Reading, Speaking and Thinking Skills & 9 & 6,2068 \\
Creative Drama & 8 & 5,5172 \\
Gifted Individuals and Creativity & 7 & 4,8275 \\
Curriculum Programs and Creativity & 6 & 4,1379 \\
Creativity in the Context of Teaching Approaches & 5 & 3,4482 \\
Creativity in the Context of Student and Teacher Views & 5 & 3,4482 \\
Creativity in The Context of Art and Literature Products & 4 & 2,7586 \\
Teaching Materials and Creativity & 3 & 2,0689 \\
Creative Individual Characteristics & 2 & 1,3793 \\
Individuals with Special Needs and Creativity & 2 & 1,3793 \\
Perceptions towards the Concept of Creativity & 2 & 1,3793 \\
Relationship Between Instructional Technologies and Creativity & 1,3793 \\
Components of Creativity & 0,6896 \\
Creativity Education & 1 & 1 \\
Total & 1 & 145 \\
\hline
\end{tabular}

\section{Discussion and Conclusion}

For the first research question about the distribution of creativity-related theses according to years and education, a total of 145 graduate studies were found. While the majority of this number (114) was graduate studies, the doctoral studies remained a small number (31) according to the collection. A similar situation occurs in Oğuz Hacat and Demir's study conducted in 2019, which examined theses on literacy in the field of education. In their study, the researchers stated that graduate theses are almost one-third of the doctoral theses. In studies related to many different fields and topics in which thesis work is examined also, again, the excessiveness of graduate theses compared to doctoral theses is remarkable (Kurtdede-Fidan \& Öner, 2018; Küçükoğlu \& Ozan, 2013; Karadağ, 2014; Şahin, Göğebakan Yıldız \& Duman, 2011; Akyol \& Yavuzkurt, 2016). This situation can be explained by the fact that the number of graduate studies is higher than the number of graduate degree programs compared to the doctoral programs in the institutes in Turkey. In addition, the fact that the doctoral process covers a longer process and the number of people attending this education is less can be shown among the factors of this situation. It is seen that the largest number of thesis studies took place in 2014 and the least in 2005 . Given the number of theses published and unpublished by year, it can be said that as of 2019, graduate thesis studies on creativity is starting to increase again. Despite this increase and thesis work published over fifteen years, the rate of study in the field of education related to creativity, one of the most basic life skills, can be said to be insufficient. The fact that only thirty-one doctoral thesis related to the subject has been studied in fifteen years can be considered that such an important skill has been overshadowed by other subjects in graduate studies.

In Turkey, it is observed that graduate studies related to the education-training dimension of creativity have been conducted in a total of fifty-two higher education institutions since 2005. Gazi University, with its twenty thesis studies, has been the institution that does the most thesis studies on the relation between creativity and education. Again, in the studies conducted by many researchers on different subjects, Gazi University was found to be the university that produced the most thesis studies (Bahar \& Kiras, 2017; Şahin, Göğebakan Y1ldı \& Duman, 2011; Oğuz Haçat \& Demir, 2018; Dilek, Baysan \& Öztürk, 2018; Oğuz Haçat \& Demir, 2019). Günay's study in 2018 revealed that Gazi University ranked third in Turkey in the number of graduate students. This explains the reason why the university has top-ranked graduate studies in many different fields. Of course, the high numbers of 
creativity-education related thesis publications could also be explained with the interest of the faculty and students in the field. Gazi University was followed by Dokuz Eylül University with twelve graduate studies and Marmara University with nine graduate studies. Oğuz Haçat and Demir (2019), in their study of graduate theses on literacy in the field of education, examined the 1998-2019-time period. The researchers who covered a wide period reached a total of 308 graduate studies. This study also showed that the intensity was after 2005 and that graduate publications increased in the process similar to the current study. However, it can be said that the number of thesis publications on creativity is far behind compared to this subject.

In the part where graduate theses about creativity in education are dealt with according to the institutes in which they are published, it is observed that most studies are done at the institute of educational sciences. The institute of social sciences, the institute of science, and the institute of health sciences follow this. Almost all of the theses made under the umbrella of these institutes were produced in teacher-training departments. The fact that the educational studies performed at the institute of social sciences and the institute of natural and applied sciences was conducted in these institutes may be thought to be due to the absence of the institute of educational sciences in the universities in which they were studied during the period of their studies. Günay stated that the number of educational sciences institutes in Turkey according to statistics for 2018 is 43 and the total number of students is 35.763 (Günay, 2018). This data shows that educational science institutes have had a wide network and number of students in recent years.

In the distribution of theses, where creativity is combined with education, according to the disciplines, there is a wide range that attracts attention. It was seen that creativity in education was discussed and published as a graduate thesis in twenty-eight different areas. In addition to this wide range of disciplines, when one looks at the number of studies done in these fields, it is seen that several publications have been made in some disciplines and no studies have been done in some disciplines. This suggests that new studies can be conducted on this subject. When considered as a discipline, it is seen that most studies are conducted in science education, while classroom Education is second in the list and the list goes on. In the field of science education, the background and intensity of the studies related to creativity appear to be more dated, but it is observed that this skill has been specifically investigated in the field of science (Akcanca \& Özsevgeç, 2016; Candar, 2009; Aktamış \& Can, 2007; Demirci, 2007). In addition, Erdem also went into a categorization according to disciplines in his study, in which he examined theses on media literacy, which he published in 2018 (Erdem, 2018). The researcher stated that the studies he examined varied in disciplines in the field of education. However, in our current study, it is difficult to say that the field-thesis variety of creativity is sufficient.

When the method parts of theses on creativity in education are examined, it is observed that the number of studies using the quantitative method is quite high compared to the qualitative and mixed methods. The use of qualitative and mixed methods is close to each other. There are many similar studies carried out in different areas that reveal that quantitative studies are used more frequently (Akyol \& Yavuzkurt, 2016; Erdem, 2018; Oğuz Haçat \& Demir, 2019; Kahyaoğlu, 2016; Küçükoğlu \& Ozan, 2013; Aydın, Selvitopu, \& Kaya, 2018; Ahi \& Kıldan, 2013; Alpaydın \& Erol, 2017; Karadağ, 2009). In the quantitative part, scanning and experimental methods were used the most. Similar results are also included in Bahar and Kiras' study (2017). Studies that prefer qualitative methods have benefited from the case study and document review. The studies performed by the mixed method made more use of the nested pattern and the explanatory sequential pattern. This data indicates that one hundred and twenty-five studies were conducted with one type of research method, that research was not supported by different types of data, and that different methods were not used to cover each other's weaknesses. In order to eliminate this weakness, many researchers suggest that research should be carried out by the mixed method (Creswell \& Plano Clark, 2015; Johnson \& Onwuegbuzie, 2004; Fırat, Kabakçı Yurdakul, \& Ersoy, 2014).

When looking at the data collection tools of the research examined, it was observed in a significant part of the research used one type of data collection tool (44/145), most of the research used two types (66/145), some of them used three types (17/145) and four types are used rarely (6/145). In a few studies, no information has been found about data collection. Due to the fact that the quantitative method is more preferred in graduate theses on creativity, the use of scale is the preferred data collection tool in the first place. Qualitative studies, on the other hand, prefer the use of more forms, while the variety of data collection tools used in mixed methods varies. There are many studies that can be encountered with similar results (Kütükcü, 2017; Küçükoğlu \& Ozan, 2013; Bahar \& Kiras, 2017). Researchers have been seen to use data collection tools that conform to the nature of their research. However, as a result of the research, it was concluded that one or two types of data collection tools were used in most of the studies examined. Collecting data with one or two data collection tools sometimes takes the opportunity to obtain rich and deep information out of the hands of researchers. In this context, it is necessary to verify the result as far as possible with several data collection tools. (Yin, 1984 Cited in Subaşı \& Okumuş, 2017; Kılıç Tapu, 2017; Deveci \& Deveci, 
2018).

When the study groups/samplings of the graduate theses on creativity in our country are examined, it is seen that the participants are mostly composed of students. The most populous group after the students are the teachers. The number of studies that have been made a literature review and bringing different study groups together is very low. This shows that the graduate publications on creativity have failed to show richness and diversity in terms of the study group. In literature, publications in different areas and periods in which study groups are dealt with also attract attention (Aydın, Selvitopu \& Kaya, 2018; Erdem, 2018; Oğuz Haçat \& Demir, 2018; Oğuz Haçat \& Demir, 2019).

In examined studies, the "random sampling method is the most prominent one among researchers' sampling format preferences. A similar result manifests itself in different field studies. and the result coincides with the current study (Aydın, Selvitopu\&Kaya, 2018; Şara, Karadedeli \&Hasanoğlu, 2016). In addition to this sampling method, many different and varied sampling methods are included in the research examined, however, the most interesting point is that almost one in three of the research studied did not mention the way of determining the method of sampling/study group. However, in graduate studies, the methods of sampling, whether purposeful or non-purposeful, isappropriate to the spirit of the research must be stated.

When we look at the details of the selected study groups in theses examined, it is seen that the most intensive level of education consists of secondary school students. A similar situation has been seen in several previous studies (Alver \& Taştemir, 2017; Erdem, 2018; Oğuz Haçat \& Demir, 2019). The idea that creativity skills are displayed more at this level of education may explain the fact that most data collected group consists of secondary school students (Kara \& Akkaya, 2014). Following this level of education, it is observed that data is collected from various study groups at almost every level. However, the number of studies aimed at comparing different levels or collecting data together from different levels of education for the same research is very small. Collecting data from different education levels will allow researchers to look at the issue from a wider perspective. In addition, given that creativity is a skill that can be developed through practice and over time (Gartenhaus, 1997), measuring continuity (process) over a certain period can reveal a clearer picture. Of course, it will not be right to say the result is wrong, because the nature of some studies makes it possible to collect data from a single level of education.

In our analysis of what is the context of titles in which creativity is studied, we concluded that researches focus on certain concepts. A similar situation and intensity can be seen in the study in which Bahar \& Kiras (2017) examined publications entitled environmental education. Another study, which concluded the similarity of topics in graduate studies, was published by Alver \& Taştemir (2017). Considering that there are currently few graduate studies conducted on creativity, it can be said that certain titles are being circulated. Studying different aspects of creativity in the context of different titles will not only provide us with more detailed information about the skill of creativity but also with a number of facts about the skill, if any, that are still unknown.

\section{Recommendation}

Some recommendations can be made based on the results obtained from this study, in which the graduate thesis related to the subject of creativity is examined. The educational dimension of creativity needs to be further studied in all life-related areas. In order to bring new solutions to the ever-increasing problems of everyday life, new ideas and suggestions for solutions are needed. Creativity is a skill that is directly related to life and it should not be forgotten that more comfortable solutions could be brought to the problems encountered in current life in areas where creativity is important. Increasing the number of mixed-method researches in graduate studies, which are very few in number, will increase the number of publications with richer and deeper information. At this point, researchers are recommended further use of mixed method research in their graduate studies. In graduate research, it is recommended that researchers who will conduct research on abilities such as skill, etc. that progress through a specific process should collect data from different levels of education as well as from different levels of education and look at the process with a holistic approach.

\section{References}

Ağluç, L. (2013). Sanat Yaratıc1lık Bağlamında İnsan Ve Yaratma Güdüsü. Mediterranean Journal of Humanities, 3(1), 1-14. https://doi.org/10.13114/MJH/20131645

Ahi, B., \& Kıldan, A. O. (2013). Türkiye'de Okulöncesi Eğitimi Alanında Yapılan Lisansüstü Tezlerin İncelenmesi (2002-2011). Mehmet Akif Ersoy Üniversitesi Eğitim Fakültesi Dergisi, 13(27), 23-46.

Akcanca, N., \& Özsevgeç, L. C. (2016). Fen Bilimleri Öğretmen Adaylarının Yaratıcıllğa İlişkin Düşüncelerinin 
Belirlenmesi. Bayburt Eğitim Fakültesi Dergisi, 11(2), 391-413.

Akkaşoğlu, S., Akyol, C., Ulama, Ş. \& Zengin, B. (2019). Tarım Turizmine Yönelik Hazırlanan Lisansüstü Tezlerin Bibliyometrik Analizi. Journal of Tourism and Gastronomy Studies, 7(2), 1193-1218. https://doi.org/10.21325/jotags.2019.416

Aktamış, H., \& Ergin, Ö. (2006). Fen Eğitimi ve Yaratıcılık. Dokuz Eylül Üniversitesi Buca Eğitim Fakültesi Dergisi, 20,77-83.

Aktamış, H., \& Can, B. T. (2007). Fen Öğretmen Adaylarının Yaratıcılık İnançları. E-Journal of New World Sciences Academy, 2(4), 484-499.

Akyol, B., \& Yavuzkurt, T. (2016). Türkiye'de Lisansüstü Tezlerde Eğitim Denetimi. Uluslararası Türkçe Edebiyat Kültür Eğitim (TEKE) Dergisi, 5(2), 908-926. https://doi.org/10.7884/teke.631

Alpaydın, Y., \& Erol, İ. (2017). Examination of Postgraduate Theses and Dissertations in The Field Of Education Economics in Turkey. Marmara University Atatürk Education Faculty Journal of Educational Sciences, 45(45), 23-41. https://doi.org/10.15285/maruaebd.292105

Alver, M., \& Taşdemir, L. (2017). Konuşma Becerisi Üzerine Yapılan Lisansüstü Tezlerin İncelenmesi. International Journal of Languages' Education and Teaching, 5(3), 451-462. http://doi.org/10.18298/ijlet.2041

Ananiadou, K., \& Claro, M. (2009). 21st century skills and competences for new millennium learners in OECD countries. OECD Education Working Papers, No. 41, OECD Publishing. http://dx.doi.org/10.1787/218525261154

Aral, N. (1999). Sanat Eğitimi-Yaratııılık Etkileşimi. Hacettepe Üniversitesi Eğitim Fakültesi Dergisi, 15, 11-17.

Atasoy, B., Kadayıfçı, H., \& Akkuş, H., (2017). Bilimsel Yaratıcılı̆̆ı Destekleyen Öğretimin Maddelerin Ayrılması Konusundaki Öğrenci Çizimlerine Etkisi. Mehmet Akif Ersoy Üniversitesi Ĕ̆itim Fakültesi Dergisi, 42, 83-104. https://doi.org/10.21764/efd.76520

Aydın, A., Selvitopu, A., \& Kaya, M. (2018). Sınıf Yönetimi Alanındaki Lisansüstü Tezlerin İncelenmesi. Abant İzzet Baysal Üniversitesi Eğitim Fakültesi Dergisi, 18(1), 41-56. https://doi.org/10.17240/aibuefd.2018..-382251

Bahar, M., \& Kiras, B. (2017). Türkiye'de Yayımlanan Çevre Eğitimi Konulu Makale ve Tezlerin Genel Analizi. Abant İzet Baysal Üniversitesi Ĕ̈itim Fakültesi Dergisi, 17(4), 1702-1720.

Bowen, G. A. (2009). Document Analysis As a Qualitative Research Method.Qualitative Research Journal, 9(2), 27-40. https://doi.org/10.3316/QRJ0902027

Büyüköztürk, Ş., Kılıç Çakmak, E., Akgün, Ö.E., Karadeniz, Ş., \& Demirel, F. (2011). Bilimsel Araştırma Yöntemleri. Ankara: Pegem Akademi Yayınları.

Can Yaşar, M., \& Aral, N. (2010). Yaratıcı Düşünme Becerilerinde Okul Öncesi Öğretimin Etkisi. Kuramsal Ĕgitimbilim, 3(2), 201-209.

Can Yaşar, M., \& Aral, N. (2011). Altı Yaş Çocuklarının Yaratıcı Düşünme Becerilerine Sosyo-Ekonomik Düzey ve Anne Baba Öğrenim Düzeyinin Etkisinin İncelenmesi. Kuramsal Eğitimbilim, 4(1), 137-145.

Candar, H. (2009). Fen Eğitiminde Yaratıcı Düşünme Öğretim Tekniklerinin Öğrencilerin Akademik Başarı, Tutum ve Motivasyonlarına Etkisi. Marmara Üniversitesi, Eğitim Bilimleri Enstitüsü. İstanbul.

Cannatella, H. (2004). Embedding Creativity in Teaching and Learning. Journal of Aesthetic Education, 38(4), 59-70. https://doi.org/10.2307/3527376

Craft, A. (2001). An analysis of research and literature on creativity in education. Qualifications and Curriculum Authority, 51(2), 1-37.

Creswell, J. W., \& Plano Clark, V. L. (2015). Karma Yöntem Araştırmaları (Ed. Yüksek Dede ve Selçuk Beşir Demir). Ankara: Anı Yayıncılık.

Demir, T. (2013). İlköğretim Öğrencilerinin Yaratıcı Yazma Becerileri İle Yazma Özyeterlilik Algısı İlişkisi Üzerine Bir Çalışma. Uluslararası Türkçe Edebiyat Kültür Eğitim Dergisi, Sayı: 2(1), 84-114.

Demirci, C. (2007). Fen Bilgisi Öğretiminde Yaratıcılı̆̆ın Erişi ve Tutuma Etkisi.Hacettepe Üniversitesi Eğitim Fakültesi Dergisi, 32(32), 65-75. Retrieved from https://dergipark.org.tr/tr/pub/hunefd/issue/7804/102312

Deveci, B., \& Deveci, B. (2018). Örnek Olay Çalışmasına İlişkin Teorik Bir Değerlendirme. Social Sciences Studies Journal, 4(13), 126-135. http://dx.doi.org/10.26449/sssj.319 
Dikici, A. (2006). Sanat Eğitimi ve Öğrencilerin Yaratıc1lı Düzeyleri. Eğitim ve Bilim, 31(139), 3-9.

Dikmenli, Y., Öztürk Demirbaş, Ç., \& Yakar H. (2018). Türkiye'de Milli Parklar Konusunda Hazırlanan Lisansüstü Tezlerin Genel Eğilimleri. Uluslararası Toplum Araştırmaları Dergisi, 9(16), 1750-1769. https://doi.org/10.26466/opus.470971

Dilek, A., Baysan, S., \& Öztürk, A. A. (2018). Türkiye'de Sosyal Bilgiler Eğitimi Üzerine Yapılan Yüksek Lisans Tezleri: Bir İçerik Analizi Çalışması. Turkish Journal of Social Research/Turkiye Sosyal Arastırmalar Dergisi, 22(2), 581-602.

Dolmaz, (2017). Sosyal Bilgiler Öğretiminde Tarihsel Roman Kullanımının Yaratıcı Yazma Becerilerine Etkisi. (Yayımlanmamış Doktora Tezi). Erzincan Üniversitesi, Sosyal Bilimler Enstitüsü, Erzincan.

Dolmaz, M., \& Kaya, E. (2018). 7. Sınıf Öğrencilerinin Yaratıcı Yazma Becerileri ve Dilsel Becerileri Arasındaki İlişkinin İncelenmesi. Uluslararası Sosyal Bilgilerde Yeni Yaklaşımlar Dergisi (IJONASS), 2(1), 22-41.

Erdem, C. (2018). Medya Okuryazarlığı Araştırmalarında Eğilimler: Lisansüstü Tezlere Yönelik Bir İçerik Analizi.Kuramsal Ĕgitimbilim Dergisi, 11(4) , 693-717. https://doi.org/10.30831/akukeg.390260

Ersükmen, E. (2010). İlköğretim Fen ve Teknoloji Ders Öğretmenlerinin Yaratıcıllk Kavramına İlişkin Görüşleri. (Yayımlanmamış Yüksek Lisans Tezi). Dokuz Eylül Üniversitesi, Eğitim Bilimleri Enstitüsü, İzmir.

Fırat, M., Kabakçı Yurdakul, I., \& Ersoy, A. (2014).Bir Eğitim Teknolojisi Araştırmasına Dayalı Olarak Karma Yöntem Araştırması Deneyimi. Eğitimde Nitel Araştırmalar Dergisi, 2(1), 65-86. https://doi.org/10.14689/issn.2148-2624.1.2s3m

Gartenhaus, A. R. (1997). Minds in Motion-Using Museum To Expand Creative Thinking. (Trans. Ruhiser Mergenci and Bekir Onur). Ankara: Ankara Üniversitesi Çocuk Kültürü Araştırma ve Uygulama Merkezi Yayınları.

Gök, B., \& Erdoğan, T. (2011). Sınıf Öğretmeni Adaylarının Yaratııı Düşünme Düzeyleri ve Eleştirel Düşünme Eğilimlerinin İncelenmesi. Ankara Üniversitesi Eğitim Bilimleri Fakültesi Dergisi, 44(2), 29-51. https://doi.org/10.1501/Egifak_0000001223

Gökalp, M. (2016). Çocukta Yaratıcılık ve Yaratıcı Çocuk Etkinliklerinin Yaratıcılık ve Geliştirilmesi Dersinde Okul Öncesi Bölümü Öğrencilerine Olan Etkisi (Samsun Eğitim Fakültesi Örneği). Manas Sosyal Araştırmalar Dergisi, 5(3), 25-36.

Günay, D. (2018). Türkiye'de Lisansüstü Eğitim Ve Lisansüstü Eğitime Felsefi Bir Bakış. Üniversite Araştırmaları Dergisi, 1(2), 71-88. https://doi.org/10.26701/uad.450965

Gür Erdoğan, D., Kaya Uyanık, G., \& Canan Güngören, Ö. (2018). Aktif Öğrenmeye İlişkin Lisansüstü Tezlerin Yapısal İncelenmesi. Sakarya University Journal of Education, 8(1), 111-125. https://doi.org/10.19126/suje.346975

Hotaman, D. (2011). Eğitim Fakülteleri Kendi Öğrencilerini Seçebilir mi. Kuramsal Eğitimbilim, 4(1), 126-136.

Işık, A. D. (2013). Sınıf Öğretmenlerinin Yaratıcı Bireyler Yetiştirmede Görev ve Sorumlulukları. The Journal of Academic Social Science Studies, 6(6), 585-601. http://dx.doi.org/10.9761/JASSS1611

İslamoğlu, A. H., \& Alnıaçı, Ü. (2014). Sosyal Bilimlerde Araştırma Yöntemleri. İstanbul: Beta Basım Yayım Dağıtım A.Ș.

Johnson R. B., \& Onwuegbuzie A. J. (2004). Mixed Methods Research: A Research Paradigm Whose Time Has Come. Educational Researcher, 33(7), 14-26. https://doi.org/10.3102/0013189X033007014

Kahyaoğlu, M. (2016). Türkiye'de Çevre Eğitimi Üzerine Yapılan Araştırmalar: Bir İçerik Analizi Çalışması. Marmara Coğrafya Dergisi, (34), 50-60.

Kara, Ö. T., \& Akkaya, A. (2014). Kurgusal Çocuk Yazını Ürünlerinde Çocukların Hayal Gücü ve Yaratıcılığını Etkileyen Boyutlar. (Ed. Bülent ÖZKAN), Çocuk Yazını Araştırmaları, Adana: Karahan Kitabevi, ss. 217-228.

Kara, Ş., \& Şençiçek, S. (2015). Yaratıcı Çocuk Yetiştirmede Problemler ve Çözüm Önerileri. Adnan Menderes Üniversitesi Ĕ̈itim Bilimleri Dergisi, 6(2), 90-97.

Karabey, B. (2010). Illköğretimdeki Üstün Yetenekli Öğrencilerin Yaratıcı Problem Çözmeye Yönelik Erişi Düzeylerinin ve Kritik Düşünme Becerilerinin Belirlenmesi. (Yayımlanmamış Doktora Tezi), Dokuz Eylül Üniversitesi, Eğitim Bilimleri Enstitüsü, İzmir.

Karadağ, E. (2009). Eğitim Bilimleri Alanında Yapılmış Doktora Tezlerinin Tematik Açıdan İncelemesi. Journal of 
Kirsehir Education Faculty, 10(3), 75-87.

Karadağ, R. (2014). Okuma İlgisi, Tutumları ve Alışkanlığı Konusunda Yapılmış Çalışmaların Lisansüstü Tezlere Dayalı Analizi: YÖK ve ProQuest Veri Tabanları Örneklemi.Pamukkale Üniversitesi Eğitim Fakültesi Dergisi, 35(1), 1-17. https://doi.org/10.9779/PUJE619

Karakuş, M. (2001). Eğitim ve Yaratıcılık. Eğitim ve Bilim, 26(119), 3-7.

Kesicioğlu, O. S., \& Deniz, Ü. (2014). Okul Öncesi Öğretmen Adaylarının Öğretmenlik Mesleğine İlişkin Tutumları ile Eleştirel Düşünme ve Yaratıcılık Becerileri Arasındaki İlişkinin İncelenmesi. International Periodical For The Languages, Literature and History of Turkish or Turkic, 9(8), 651-659. http://dx.doi.org/10.7827/TurkishStudies.7206

Kılıç, B., \& Tezel, Ö. (2012). İlköğretim Sekizinci Sınıf Öğrencilerinin Bilimsel Yaratıcılık Düzeylerinin Belirlenmesi. Türk Fen Eğitimi Dergisi, 9(4), 84-101.

Kılıç Tapu, I. (2017). Müzik Öğretmenliği Eğitimi Sürecinin Lisansüstü Tezlerdeki Görünümü. Journal of Social and Humanities Sciences Research, 4(11), 504-513. http://dx.doi.org/10.26450/jshsr.80

Kiper, S. (2016). Anaokuluna Devam Eden 48-71 Ay Aralı̆̆ındaki Çocukların Yaratıcılık Düzeyleri ile Sosyal Becerileri Arasındaki İlişki. (Yayımlanmamış Yüksek Lisans Tezi). Çağ Üniversitesi, Sosyal Bilimler Enstitüsü, Mersin.

Kurtdede-Fidan, N., \& Öner, Ö. (2018). Değerler Eğitimine Yönelik Yapılan Lisansüstü Tezlerin İncelenmesi.Uluslararası Alan Ĕ̆itimi Dergisi, 4(1), 1-17. https://doi.org/0.32570/ijofe.388289

Kurtoğlu, M., \& Seferoğlu, S. (2013). Öğretmenlerin Teknoloji Kullanımı ile İlgili Türkiye Kaynaklı Dergilerde Yayımlanmış Makalelerin İncelenmesi. Journal of Instructional Technologies and Teacher Education, 2(3), 1-10. Retrieved from https://dergipark.org.tr/tr/pub/jitte/issue/25082/264707

Kurtzberg, T. R. (2005). Feeling creative, being creative: An empirical study of diversity and creativity in teams. Creativity Research Journal, 17(1), 51-65. https://doi.org/10.1207/s15326934crj1701_5

Küçükoğlu, A., \& Ozan, C. (2013). Sınıf Öğretmenliği Alanındaki Lisansüstü Tezlere Yönelik Bir İçerik Analizi. International Journal of Eurasia Social Sciences, 2013(12), 27-47. https://doi.org/10.30831/akukeg.390260

Kütükcü, A. (2017). Türkiye’de Kadın Liderlik Alanında Yapılan Lisansüstü Tezlerin İncelenmesi. Kadın Araştırmalarl Dergisi, (15), 26-47.

Maxwell, J. A. (2007). Qualitative Research Design: An Interactive Approach Applied Social Research Methods Series. California: Sage Publications.

Miles, M. B., \& Huberman, A. M. (1994). Qualitive Data Analysis (2nd ed.). California: SAGE.

Oğuz Haçat, S., \& Demir, F. B. (2018). Sosyal Bilgiler Eğitimi Üzerine Yapılan Doktora Tezlerinin Değerlendirilmesi (2002-2018). Avrasya Uluslararası Araştırmalar Dergisi, 6(15), 948-973. https://doi.org/10.33692/avrasyad.510136

Oğuz Haçat, S., \& Demir, F. B. (2019). Eğitim Alanında Okuryazarlık Üzerine Yapılan Lisansüstü Tezlerin Analizi. The Journal of Anatolian Cultural Research (JANCR), 3(2), 116-145.

Onur, D., \& Zorlu, T. (2017). Yaratıcılı Kavramı ile İlişkili Kuramsal Yaklaşımlar. Insan ve Toplum Bilimleri Araştırmaları Dergisi, 6(3), 1535-1552.

Oruç Erdoğan, E. (2018). A review on The Contents of The Graduate Thesis Conducted on Financial Literacy Turkey. Journal of Current Researches on Social Sciences, 8(4), 491-510.

Oruç, Ş., \& Ulusoy, K. (2008). Sosyal Bilgiler Öğretimi Alanında Yapılan Tez Çalışmaları. Selçuk Üniversitesi Ahmet Keleşoğlu Eğitim Fakültesi Dergisi, 26, 121-132.

Ömeroğlu, E. (1988). Yapıcı ve Yaratıcı Nesiller Yetiştirme. Eğitim ve Bilim, 12(67), 46-49.

Öncü, E. Ç. (Ed). (2018). Erken Çocukluk Döneminde Yaratıcılık ve Geliştirilmesi. Ankara: Pegem Akademi Yayıncilik.

Öz-Aydın, S., \& Ayverdi, L. (2014). BİLSEM'e Kayıtlı Olan ve Olmayan Öğrencilerin Çevre Sorununa Çözüm Önerilerinin Bilimsel Yaratıcılık Açısından Karşılaştırılması. Türk Fen Eğitimi Dergisi, 11(1), $25-41$. https://doi.org/10.12973/tused.10101a

Özerbaş, M. A. (2011). Yaratıcı Düşünme Öğrenme Ortamının Akademik Başarı ve Bilgilerin Kalıcılığa Etkisi. Gazi 
Ĕ̌itim Fakültesi Dergisi, 31(3), 675-705.

Özkan, U. B. (2019). Eğitim Bilimleri Araştırmaları İçin Doküman İnceleme Yöntemi. Ankara: Pegem Akademi.

Öztürk, E. (2001). Yaratıcılık ve Eğitim. Sakarya Üniversitesi Eğitim Fakültesi Dergisi, 1, 158-164.

Şahin, M., Göğebakan Yıldız, D., \& Duman, R. (2011). Türkiye'deki Sosyal Bilgiler Eğitimi Tezleri Üzerine Bir Değerlendirme. Sosyal Bilgiler Eğitimi Araşstırmaları Dergisi, 2(2), 96-121.

Sönmez, D. (2017). Eğitim ve Öğretim Alanındaki Çevre Etiği Tez Çalışmalarının İncelenmesi. Gaziantep University Journal of Educational Sciences, 1(1), 55-66.

Subaşı, M., \& Okumuş, K. (2017). Bir Araştırma Yöntemi Olarak Durum Çalışması. Atatürk Üniversitesi Sosyal Bilimler Enstitüsü Dergisi, 21(2), 419-426.

Şara, P., Karadedeli, İ., \& Hasanoğlu, G. (2016). Sınıf Yönetimi Alanında Ulakbim'de Taranan Makalelerin İncelenmesi. Kirlkkale Üniversitesi Sosyal Bilimler Dergisi, 6(2), 291-307.

Şenyurt, S., \& Özer Özkan, Y. (2017). Eğitimde Ölçme ve Değerlendirme Alanında Yapılan Yüksek Lisans Tezlerinin Tematik ve Metodolojik Açıdan İncelenmesi. İlköğretim Online, 16(2), 628-653. https://doi.org/10.17051/ilkonline.2017.304724

Şimşek, N., \& Yaşar, A. (2019). GeoGebra İle İlgili Lisansüstü Tezlerin Tematik ve Yöntemsel Eğilimleri: Bir İçerik Analizi. Turkish Journal of Computer and Mathematics Education, 10(2), 290-313. https://doi.org/10.16949/turkbilmat.450566

Tezci, E., \& Gürol, A. (2003). Oluşturmacı Öğretim Tasarımı ve Yaratıcılık. The Turkish Online Journal of Educational Technology, 2(1), 50-55.

Torrance, E. P. (1977). Creativity in the Classroom; What Research Says to the Teacher. National Education Association, Washington, DC.

Yanpar Yelken, T. (2009). Öğretmen Adaylarının Portfolyoları Üzerinde Grup Odaklı Yaratıcılık Temelli Materyal Geliştirmenin Etkileri. Eğitim ve Bilim, 34(153), 83-98.

Yenilmez, K., \& Yolcu, B. (2007). Öğretmen Davranışlarının Yaratıcı Düşünme Becerilerinin Gelişimine Katkısı. Manas Sosyal Bilimler Dergisi, 18, 95-105.

Yıldırım, A., \& Şimşek, H. (2006). Sosyal Bilimlerde Nitel Araştırma Yöntemleri (10. Baskı). Ankara: Seçkin Yayincilik.

Yontar, A. (1993). Insanda Yaratıcılı̆̆ın Gelişimi. Ed. Ayșegül Ataman in Yaratıcılık ve Ĕ̈itim. Ankara: Şafak Matbaac1lık, 17-29. Retrieved from http://www.ted.org.tr/pdf/ted_yaraticilik_ve_egitim_ocr.pdf

\section{Copyrights}

Copyright for this article is retained by the author(s), with first publication rights granted to the journal.

This is an open-access article distributed under the terms and conditions of the Creative Commons Attribution license (http://creativecommons.org/licenses/by/4.0/). 